Sonja

Klemenčič

vodja središča

za razvoj in

svetovanje

Andragoški center

Slovenije

\title{
KURIKULARNA PRENOVA PROGRAMOV TUJIH JEZIKOV ZA ODRASLE
}

\section{Kaj o izobraževalnih programih tuji jezikov za odrasle menijo učitelji?}

$P_{n}$ ževanje odraslih deluje ob osmih ostalih tudi programska kurikularna komisija za javne programe izobraževanja odraslih iz 7 . člena Zakona o izobraževanju odraslih. Ime je grdo in nepraktično, a doslej nismo našli takega, ki bi odražalo vsebino dela komisije. V pristojnosti te komisije so namreč vsi javni (verificirani) izobraževalni programi za odrasle, ki ne sodijo med programe poklicnega ali strokovnega izobraževanja za pridobitev izobrazbe oz. niso splošni programi, ki dajejo stopnjo izobrazbe. ${ }^{1}$ Naloga programske komisije je, da izmed izobraževalnih programov, ki sodijo v njeno pristojnost, izbere tiste, ki jih kaže prenoviti v času, ko v Sloveniji poteka projekt Kurikularna prenova. Programska komisija organizira izdelavo spremenjenega kurikulu$\mathrm{ma}$ in ga posreduje $\mathrm{v}$ postopek potrditve.

Ko smo se članice programske komisije v marcu letošnjega leta prvič sestale, smo ugotovile, da programov, ki sodijo $\mathrm{v}$ našo pristojnost, ni tako malo, saj poleg programov, ki so bili sprejeti na strokovnem svetu za vzgojo in izobraževanje, obstaja kar nekaj javnih izobraževalnih programov, ki so bili sprejeti na drugačen način (potrdila so jih razna ministrstva ali druge institucije). Odločiti smo se morale za nekakšen vrstni red, saj vsèga dela ni mogoče opraviti naenkrat. Pri tem so nas vodili naslednji kriteriji:

- koliko časa je minilo od sprejema izobraževalnega programa (predvidevati je mogoče, da »starejši « programi zahtevajo dopolnitve, ki jih prinaša razvoj ustrezne stroke);

- kakšno je povpraševanje odraslih po vključevanju $\mathrm{v}$ določen izobraževalni program (najprej je dobro prenavljati programe, $\mathrm{v}$ katere se vključuje veliko odraslih);
Tako je po skrbnem tehtanju padla odločitev, da se najprej lotimo izobraževalnih programov za tuje jezike. Ti programi so bili sprejeti na ustreznih strokovnih svetih v letu 1984, izvaja pa jih 72 različnih izobraževalnih organizacij za izobraževanje odraslih iz vse Slovenije. Prav učitelji iz teh organizacij so ob različnih priložnostih opozarjali, da so programi že deloma zastareli in da bi jih morali dopolniti.

\section{KRATEK OPIS VERIFICIRANIH ${ }^{2}$ IZOBRAŽEVALNIH PROGRAMOV TUJIH JEZIKOV ZA ODRASLE}

Ko govorimo o izobraževalnih programih tujih jezikov za odrasle, imamo v mislih izobraževalne programe za angleščino, nemščino, italijanščino, francoščino in madžarščino, ki jih je sprejela Posebna izobraževalna skupnost za družboslovno usmeritev, in sicer prve štiri na seji 30. maja 1984, zadnjega pa prav tako 30. maja leta 1988. Gre za edine javno potrjene izobraževalne programe tujih jezikov za odrasle v Sloveniji. Slušatelji, ki uspešno izpolnijo vse obveznosti, določene s temi programi, si pridobijo spričevalo, ki ima javno veljavnost $v$ celi Sloveniji. Programi ${ }^{3}$ trajajo od 430 do 450 ur. V ciljih teh izobraževalnih programov je zapisano, da "pridobljeno znanje omogoča sposobnost ustreznega sporazumevanja $s$ tujcem, branje in razumevanje besedil $\mathrm{v}$ tujem jeziku ter preprosto pisno izražanje, tako v osebnem življenju kot tudi pri opravljanju delovnih nalog in opravil«. Zapisano je, naj bi znanje, pridobljeno po tem programu, ustrezalo najmanj znanju drugega tujega jezika na srednjih šolah, čeprav nam ni znano, da bi bilo to določilo izpeljano tudi v praksi (da bi bil nekdo, ki je imel potrdilo o opravljenih obveznostih po 
tem programu, oproščen predmeta drugi tuji jezik v kakem srednješolskem programu).

Izobraževalni program je predvidel izpeljavo $\mathrm{v}$ štirih ali petih semestrih $\mathrm{v}$ treh različicah:

\begin{tabular}{|c|c|c|c|c|c|}
\hline 1 semester & 2 semester & 3. senester & 4. semesser & 6. sentester & chepel \\
\hline 180 & 112 & 112 & 70 & 1 & 40 \\
\hline 112 & 112 & 11 & 112 & 1 & 48 \\
\hline 10 & 100 & 100 & 110 & 50 & 40 \\
\hline
\end{tabular}

Zakaj je predvideno različno trajanje izobraževalnega programa (ob istih ciljih in vsebinah), iz zapisanega ni razvidno, ugibamo pa lahko, da so sestavljalci predvideli različno predznanje skupin.

Učni načrt je najobsežnejši del obravnavanega izobraževalnega programa. Najprej opredeljuje tematiko, in sicer naj bi udeleženci osvojili besedni zaklad in vsaj delno tudi pisno izražanje s področja osebnega in družbenega delovanja, znali naj bi ravnati $v$ situacijah, s katerimi se srečujemo ob obiskih v tuji$\mathrm{ni}$, sposobni se naj bi bili sporazumevati $\mathrm{v}$ zvezi s svojim delom in podjetjem, poznali naj bi terminologijo družbenoekonomske ureditve ter samoupravnih odnosov. Predvideno je, da naj bi slušatelj osvojil približno 2000 besed aktivnega besednega zaklada $\mathrm{v}$ tujem jeziku, pa tudi pasivni besedni zaklad, ki bi mu omogočal branje lažjih, pa tudi zahtevnejših besedil v tujem jeziku. Učni načrt nadalje govori o funkcijah jezika, ki jih spoznajo udeleženci izobraževalnega programa. To so komunikativni ali medsebojni odnosi, poziv, informacije, trditve, vrednotenje in izražanje čustev. Sledijo strukture jezika, ki naj jih udeleženci aktivno obvladajo, tudi $\mathrm{v}$ medsebojnih povezavah. Učni načrt pa ne obsega časovne razporeditve učne snovi (t. i. ČRUS), pač pa navaja, da ga izdela vsaka izobraževalna organizacija posebej.

V nadaljevanju izobraževalni program vsebuje dokaj natančna didaktično metodična navodila za izvedbo učnega načrta: kako udeležence seznaniti s cilji učenja, kako učinkovito učiti pravilno izgovorjavo, kako posredovati slovnico, kako uvajati novo besedje, kako vaditi razumevanje, govor, kdaj uvajati branje, kako vaditi pisanje $\mathrm{v}$ tujem jeziku in kako motivirati udeležence ne samo ob pričetku poučevanja, ampak tudi med učenjem.

Izobraževalni program ne določa učbenikov, ki se uporabljajo, pač pa le na splošno nava- ja, da se uporabljajo učbeniki, delovni zvezki, slovarji ipd.

S programom so določeni tudi normativi za oblikovanje učnih skupin: tako naj bi v skupino vključevali najmanj 10 in največ 16 udeležencev. Navedeno je, da je mogoče oblikovati tudi manjše skupine, če so udeleženci pripravljeni plačati višjo ceno. Navedeno je, da naj bi v izobraževalni organizaciji oblikovali skupine na podlagi razvrstitvenega testa ali osebnega razgovora, pri čemer razvrstitveni test $\mathrm{ni}$ vsebinsko določen. $V$ izobraževalni program se lahko vključi vsakdo, ki ima najmanj končano osnovno šolo.

Posebno poglavje izobraževalnega programa je namenjeno spremljanju, preverjanju in ocenjevanju znanja $v$ času izvajanja programa. Sestavljalci programa opozarjajo na pomen sprotnega spremljanja uspešnosti posameznikov. Sicer pa je ob zaključku posamezne stopnje ${ }^{4}$ predviden zaključni test, ki je pogoj za napredovanje $\mathrm{v}$ naslednjo stopnjo. $\mathrm{V}$ zvezi s tem izpitom so določeni pogoji za njegovo opravljanje (tako ga lahko opravljajo tudi tisti, ki so si znanje pridobili s samoizobraževanjem), sam potek izpita ter ocenjevanje. Določen je pisni in ustni del izpita, opisani so kriteriji za ocenjevanje in standardi znanja, ki se na izpitu preverjajo, pri čemer pa so to le bolj splošni opisi. ${ }^{5} \mathrm{Iz}$ programa ni razvidno, kdo oblikuje izpitna vprašanja in na kakšni ravni: ali vsi izvajalci programa skupaj ali pa vsaka izobraževalna organizacija posebej.

Zanimivo je, da je v izobraževalnem programu predvideno, da izpitno komisijo imenuje direktor izobraževalne organizacije, potrdi pa jo strokovni svet Posebne izobraževalne skupnosti za družboslovno usmeritev. Kolikor nam je znano, taka rešitev v praksi ni zaživela, nakazuje pa, da so o delnem eksternem preverjanju znanja razmišljali že $v$ 80. letih. Opisani so tudi postopki v zvezi z izpiti; kakšne listine se vodijo, kako je v primeru, ko so kandidati neuspešni, kdaj se lahko izpit ponavlja ipd.

Prav na koncu pa so dodani pogoji za učitelje in zunanje sodelavce ter izvajalsko organizacijo. Učitelji in zunanji sodelavci ${ }^{6}$ morajo imeti visoko izobrazbo, strokovni izpit, zaželena pa so tudi funkcionalna znanja. Za zunanje sodelavce je poleg tega predvideno, da morajo pred opravljanjem vzgojnoizobraže- 
valnega dela vsaj teden dni hospitirati na matični ustanovi in imeti obvezen nastop pred direktorjem ali strokovnim delavcem. Predvideno je bilo tudi sodelovanje s tujimi lektorji.

Program poleg kadrovskih pogojev opisuje, kakšne prostorske pogoje in pogoje glede opreme morajo izpolnjevati ustanove, ki želijo izvajati tak program. Navedeno je, da mora ustanova razpolagati s sodobno učno tehnologijo, vsaj enim jezikovnim laboratorijem ali specializirano učilnico, imeti mora magnetofon, kasetofon, grafoskop, diaprojektor, kinoprojektor, kasete, diafilme in drugo pisno ter slikovno gradivo.

\section{KAKO POTEKA DELO PROGRAMSKE KOMISIJE PRI PRENOVI TEH PROGRAMOV?}

Programska komisija se je dela lotila tako, da:

1. pridobiva podatke, kako so podobni programi oblikovani v tujini;

2. je pripravila metodologijo za pripravo dopolnjenih oz. spremenjenih izobraževalnih programov z navodili, da bo delo ekspertov, ki bodo pripravljali nove programe, čimbolj poenostavljeno;

3. je pripravila ter izvedla anketiranje učiteljev, ki poučujejo po teh izobraževalnih programih, da bi tako dobili celovitejši in sistematični vpogled, kako ti ocenjujejo te progra$\mathrm{me}, \mathrm{v}$ čem vidijo njihove prednosti in $\mathrm{v}$ čem slabosti.

Predlog novih/prenovlienih izobraževalnih programov bomo še pred uvedbo postopka sprejenanja preverili s skupino učiteljev praktikov. Šele po tej »verifikaciii < bomo programe predložili v obravnavo področni kurikularni komisiji za izobraževanje odraslih, ta pa jih bo, ob ugodni oceni, posredovala nacionalnemu kurikularnemu svetu. S tem pa postopek še ni zaključen: pravo potrditev bodo programi dobili šele na strokovnem svetu za izobraževanje odraslih in ko jih bo sprejel (njihov splošni del) minister za šlstvo in šport. Dokaj zapletena in s tem dolgotrajna pot, ki bo, upamo, koristna za temeljito presojo in pripravo takih programov, ki bodo zagotavljali kvaliteto, ki jih bodo učitelji radi izvajali in ki bodo prijazni do udeležencev.

Vse to bo podlaga za delo ekspertnih skupin za posamezne jezike, ki bodo $\mathrm{v}$ kratkem pričele delovati ob programski komisiji. Najprej bo pripravljen prenovljen program za učenje angleščine, kasneje pa želimo po tem vzoru dopolniti še programe za ostale jezike.

\section{NAMEN ANKETIRANIA, INŠTRUMENTARI] IN ŠTEVILO ANIKETIRANIH}

Kot smo že omenili, se nam je zdelo zelo pomembno, da pred kakršnimkoli spreminjanjem izobraževalnih programov za tuje jezike najprej za mnenje povprašamo tiste, ki te programe najbolj poznajo, to je učiteljice in učitelje. V ta namen smo pripravili pisno anketo, ki vsebuje 27 vprašanj. V anketo smo skušali zajeti tista vprašanja, ki zadevajo vse sestavine sedaj veljavnih izobraževalnih programov:

- kaj učitelji menijo o vpisnih pogojih in predvideni ciljni skupini,

- kako ocenjujejo sedaj opredeljene standarde znanja,

- kako vrednotijo predpisano vsebino,

- kakšni se jim zdijo kriteriji za vrednotenje znanja,

- kako program organizacijsko izvajajo v različnih ustanovah in kakšna so njihova stališča do tega,

- kaj menijo o trajanju programa,

- kaj menijo o pogojih za izvedbo programa ipd.

Kjer je bilo le mogoče, smo se odločili za vprašanja zaprtega tipa, da bi bilo tako mogoče odgovore lažje vrednotiti. Povsod to, seveda, ni bilo mogoče, saj smo le na ta način lahko prišli do dragocenih mnenj in stališč učiteljic in učiteljev.

Problem, na katerega smo naleteli pri izvedbi ankete, je bila pridobitev podatkov o učiteljih, ki poučujejo odrasle po teh programih. Tak seznam namreč nikjer ne obstaja, saj povečini ne gre za redno zaposleno osebje, pač pa to delo v ustanovah za izobraževanje odraslih opravljajo zunanji sodelavci. Tako bi imena in število učiteljev lahko dobili le, če bi nam bile te ustanove pripravljene odstopiti seznam svojih sodelavcev. Za pomoč smo zato zaprosili direktorje vseh tistih ustanov, ki so si pri Ministrstvu za šolstvo in šport pridobile pravico za izvajanje verificiranih programov tujih jezikov za odrasle. Takih ustanov je 72, pri čemer pa je treba upoštevati, da vse, 
kljub pravici, teh programov iz različnih razlogov ne izvajajo. Prosili smo jih, da po svoji presoji ankete posredujejo (vsem ali nekaterim) učiteljem verificiranih tujih jezikov $v$ svoji ustanovi. Iz teh razlogov ne moremo oceniti, koliko je vseh učiteljev, ki poučujejo $\mathrm{v}$ omenjenih programih, in s tem niti tega, kolikšen je delež učiteljic in učiteljev, ki so se odzvali na anketo. Ocenjujemo pa, da smo kljub vsemu dosegli odzivnost, na podlagi katere je mogoče vsaj splošno oceniti obravnavane programe. Odzvalo se je namreč 67 učiteljic in učiteljev. ${ }^{7}$

Nekoliko bolj problematično je, če bi želeli ocenjevati rezultate po posameznih jezikih. Pri nekaterih (npr. francoščina) je število učiteljev, ki so nam odgovorili, tako majhno, da odgovorov ni mogoče posploševati. Tako se od 658 veljavnih anket 29 nanaša na nemščino, 27 na angleščino, 7 na italijanščino in 2 na francoščino. Zanimivo je, da na anketo ni odgovoril niti en učitelj madžarščine. Povedali pa smo že, da so programi za vse naštete jezike, razen v poglavju o strukturah jezika, sestavljeni povsem enako, zaradi česar je mogoče ugotavljati njihove skupne dobre ali slabe lastnosti na podlagi vseh anket, ne glede na to, za kateri jezik so bile ocene dane. Res pa je, da bo treba za subtilnejše ocene programov za posamezne jezike uporabiti še druge inštrumentarije.

Anketa je bila izvedena konec aprila in v prvi polovici maja 1997, in sicer po pošti. Deloma smo jo posredovali na naslove učiteljic in učiteljev, s katerimi smo razpolagali, deloma pa na naslove ustanov, ki imajo licenco za izvajanje teh programov. Izpolnjevanje ankete je bilo anonimno, lahko pa je anketiranec pripisal svoje ime, če je to želel. Naj se ob tej priložnosti zahvalimo vsem učiteljicam in učiteljem, ki so nam prijazno, tudi kritično, odgovorili na anketo, pa tudi vsem direktorjem izobraževalnih organizacij, ki so anketo posredovali svojim učiteljem, ali pa nas obvestili, da programov iz tega ali onega razloga ne izvajajo.

\section{REZULTATI ANKETIRANJA 9}

Koliko izkušenj $\mathrm{z}$ obravnavanimi programi imajo tisti, ki so sodelovali $\mathrm{v}$ anketiranju? $\mathrm{Za}$ vrednotenje rezultatov se nam je zdelo pomembno, da ugotovimo, ali so na anketo odgovarjali učitelji, ki imajo dolgoletne izkušnje z obravnavanimi programi, ali pa začetniki. Kar 42 ali $65 \%$ učiteljev v teh programih poučuje že več kot pet let, 17 (26\%) pa od dveh do petih let. Le manjšina se je s temi programi srečala šele pred kratkim. Ta podatek je razveseljiv, saj nas navaja, da odgovori anketirancev niso rezultat kratkotrajne izkušnje, pač pa daljšega proučevanja in delovanja $z$ omenjenimi programi.

Ali anketiranci dobro poznajo opazovani izobraževalni program? To vprašanje je morda za koga čudno, poznavalci prakse, pa tudi teoretiki, ki se ukvarjajo s kurikularno teorijo, ${ }^{10}$ pa poznajo pojav, da marsikateri učitelj - zelo pogosto tudi v izobraževanju mladine sploh ne pozna izobraževalnega programa, ki ga poučuje, pač pa se ravna po predpisanih učbenikih, po izkušnjah iz lastnega izobraževanja ipd. Zato nas je zanimalo, v kolikšni meri anketiranci poznajo program, ki ga ocenjujejo, ali še bolje, ki ga izvajajo. Odgovori na vprašanje "Ali dobro poznate program $\mathrm{v}$ obliki, v kakršni je bil sprejet na strokovnem svetu RS za vzgojo in izobraževanje leta 1984 ? « so bili naslednji:

\begin{tabular}{|c|c|c|c|c|}
\hline & englejeino & nemsécina & iloliensèno & froncosèina \\
\hline Do, imam izvod programa & $20174 \%$ & $17(61 \%)$ & $4(57 \%)$ & $(100 \%)$ \\
\hline $\begin{array}{l}\text { Da, usho me je z njim } \\
\text { seznanil direklor/vodja } \\
\text { izobrożevanja v usianovi, } \\
\text { kier poucujem, vendar }\end{array}$ & & & & \\
\hline prograna sam nimam & $3(11 \%)$ & $5(17 \%)$ & $2(29 \%)$ & I \\
\hline Ne & $4(15 \%)$ & $6(21 \%)$ & $1 / 14 \%$ & 1 \\
\hline Brez odgovora & / & 1 & 1 & 1 \\
\hline
\end{tabular}

Te rezultate je treba obravnavati nekoliko previdno, saj je mogoče predvidevati, da so nekateri anketiranci menili, da bi bilo prav, da bi program poznali natančno in da so se zato izrekli, da program poznajo, čeprav to ne drži. Zakaj to trdimo, bo navedeno v nadaljevanju.

Od 65 anketirancev dobro pozna in ima izvod programa 42 anketirancev (slabi dve tretjini). $17 \%$ je takih, ki programa sploh ne poznajo, vsi ostali pa so z njim seznanjeni le posredno. Pri takih odgovorih je verjetno le težko najti opravičilo, zakaj je tako. Pri tem pa ne gre toliko za krivdo učiteljev, pač pa predvsem tistih ustanov, ki so dobile pravico do izvajanja teh programov, pa niso poskrbele niti toliko, da bi svoje učitelje seznanile $s$ programom, ki naj bi ga izvajali. 


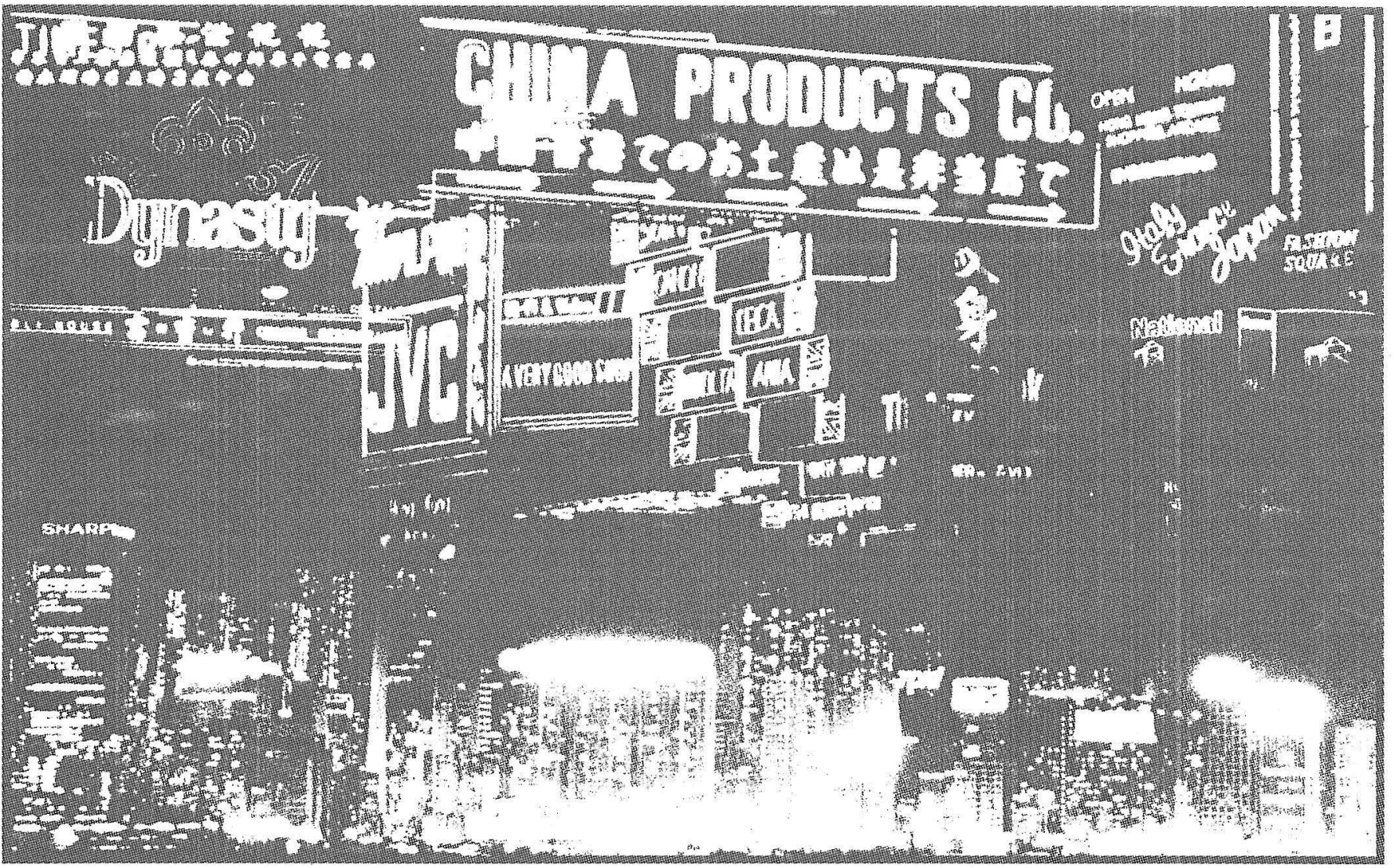

Kako anketiranci na splošno ocenjujejo izobraževalni program? $\mathrm{Na}$ to vprašanje so nam odgovarjali takole: program je zelo dober (7\%), dober (86\%), slab 4 (7\%). Za odgovor »zelo slab« se ni odločil nihče.

Kakšne so odlike in slabosti izobraževalnih programov? Preden smo anketirance podrobno vprašali, kakšne se jim zdijo posamezne sestavine opazovanih programov, smo jih zaprosili, naj nam napišejo tri njihove odlike in tri slabosti. Iz tega lahko povzamemo nekaj splošnih ugotovitev, ki veljajo za vse obravnavane programe:

- Trajanje programov je ena izmed lastnosti, ki je bila pogosto predmet ocenjevanja. Zanimivo je, da veliko učiteljev meni, da je opredeljeno trajanje programa njegova odlika, skoraj prav tako velika skupina pa navaja, da je to slabost, da je premalo ur ali pa da je ur preveč. Ker smo zbirali tudi podatke o tem, $v$ koliko urah pri posameznih izvajalcih izvedejo program (o tem več v nadaljevanju), nas je zanimalo, ali se nad trajanjem programa "pritožujejo" tisti, ki ga izvajajo tako, kot določa program, ali drugače. Skoraj brez izjeme je mogoče ugotoviti, da so se za to, da program traja premalo časa, izrekli tisti, ki program izvedejo v 450 ali pa tudi veliko več urah. Očitno je, da je del učiteljev s trajanjem zadovoljnih, drugi del pa bi želel več ur (in povečini tako že izvaja program). To je eno izmed vprašanj, ki jih kaže pri prenavljanju programov natančneje preučiti, pri čemer bo treba odločitev sprejeti predvsem na presoji, v kolikšnem času je mogoče doseči zahtevan standard znanja v povprečni populaciji, medtem ko je treba dopustiti možnost časovne fleksibilnosti izvajalcem ob upoštevanju predznanja, motivacije, interesov konkretnih skupin udeležencev.

- Standardi znanja so zopet sestavina, ki so bili zelo pogosto omenjani. Veliko bolj pogosto jih učitelji hvalijo kot grajajo. Iz tega lahko sklepamo, da jih je treba le malenkostno dodelati. Najpogostejša kritika se nanaša na to, da niso dovolj natančni.

- Učni načrt je doživel veliko pohval, pa tudi kritičnih mnenj. Rezultati nesporno kažejo, da je učni načrt med vsem, kar so učitelji pohvalili, na prvem mestu. Nekateri hvalijo učni načrt $\mathrm{v}$ celoti, več kot polovica anketirancev je pohvalilo teme, zadovoljni so z opredeljenimi slovničnimi strukturami, všeč jim je, da učni načrt enakovredno poudarja govorno, pisno in slušno funkcijo jezika, pa tudi to, da je v programu učni načrt obširneje pojasnjen. 
Razumljivo je, da imajo učitelji tudi precej predlogov, kako bi učni načrt še izboljšali. Tako opozarjajo na nekatere zastarele teme in predlagajo dodatne teme (o tem več $\mathrm{v}$ nadaljevanju).

- Ena izmed stvari, ki nas je pri prebiranju rezultatov najbolj presenetila, so bile ocene o učbenikih in drugih učnih gradivih. Že v opisu programa smo povedali, da program ne določa učbenikov, pač pa le navaja, kakšni bi morali biti. Učitelji pa zelo pogosto učbenike hvalijo, še bolj pogosto pa jih kritizirajo! Iz tega lahko izhaja več sklepanj: morda še večji delež učiteljev, ki se je tako izrekel, ne pozna izobraževalnega programa in s tem ne ve, da program ne določa učbenikov, pač pa to prepušča strokovni presoji učiteljev. Morda učbenike določijo $\mathrm{v}$ izobraževalni ustanovi (direktor, vodja jezikovnega izobraževanja?), uçitelj pa jih sprejme kot obvezne, četudi z njimi ni zadovoljen. Tako npr. nekdo navaja, da so teme $v$ učbeniku neprimerne, da jih slušatelji ne marajo, ob tem pa bi lahko sam zamenjal učbenik; nekdo drug pa predlaga, da bi morali učbenike izbirati učitelji. Drugo sklepanje je lahko, da učitelji sicer vedo, da program ne določa učbenikov, pa so ocenjevali učbenike, ki so sicer na razpolago na slovenskem tržišču in $s$ tem na izbiro pri poučevanju tujih jezikov. Iz izjav nekaterih anketirancev pa je razvidno, da sicer poznajo določila programa v zvezi z učbeniki, pri čemer so nekateri zadovoljni, da imajo možnost samostojne izbire učnih virov, drugi pa pričakujejo, da bi program določil ali pa predlagal, priporočil primerne učbenike.

- Velikost skupin (16 udeležencev) se samo manjšini učiteljev zdi primerna, več pa je takih, ki opozarjajo, da je normativ prevelik. Tako stališče niti ne preseneča, če vemo, da se je $\mathrm{v}$ praksi uveljavil zelo pogost normativ 8 udeležencev na skupino.

- Program kot vstopni pogoj določa končano osnovno šolo. Dva učitelja sta to ocenila kot odliko programa, medtem ko jih več navaja, da to ni ustrezen kriterij, da bi morali opredeliti take kriterije, ki bi zagotavljali večjo homogenost predznanja udeležencev $\mathrm{v}$ skupini. Pred vključitvijo v program bi morali ugotavljati predznanje.

- Zelo pogosto so se učitelji odločali za ocenjevanje kriterijev za vrednotenje znanja, po- stopke sprotnega spremljanja napredovanja udeležencev, testov ipd. Pri tem se je izrazito pokazalo, kateri učitelji učijo na ljudskih univerzah in kateri ne. Zveza ljudskih univerz je namreč pripravila enotne in podrobnejše kriterije za preverjanje znanja ter tudi teste. Tisti učitelji, ki poučujejo na ljudskih univerzah, so se pozitivno ali negativno izrekali do teh gradiv (ki pa, seveda, niso sestavni del verificiranega programa), medtem ko so drugi kot slabost navajali prav to, da ni enotnih kriterijev, da so ti kriteriji preohlapni (tako kot so zapisani $\mathrm{v}$ veljavnem programu), da ni standardiziranih testov, da elementi izpita niso natančno določeni ipd. Kot pomembno opozorilo kaže izpostaviti, da so učitelji opozorili na to, da bi morali imeti določene kriterije za prehod iz ene stopnje (semester) v drugo.

Kako učitelji ocenjujejo opredelitev ciljne skupine? $\mathrm{V}$ programu je zapisano, da je namenjen vsem odraslim, ki so končali osnovno šolo. To je hkrati tudi vstopni pogoj, čeprav $_{5}$ ni jasno, ali program izhaja iz predznanja tujega jezika, ki ga daje osnovna šola, ali pa je tak vstopni pogoj le starostna omejitev in ni predvideno predznanje tujega jezika. Rezultati kažejo, da se učiteljem zdi opredelitev ciljne skupine kar ustrezna (tako se jih je opredelilo skoraj $70 \%$ ). Razlogi za tak rezultat lahko tičijo v tem, da je učiteljem pomembno to, da vedo, da se bodo ukvarjali z odraslimi (ali tudi mladino), medtem ko se jim druge značilnosti ciljne skupine ne zdijo pomembne.

Tiste, ki so napisali, da se jim taka opredelitev ciljne skupine ne zdi ustrezna, smo povprašali, kateri kriteriji bi bili po njihovem ustreznejši. Odgovori so bili taki: angleščina: sedem anketirancev $(64 \%$ od tistih, ki so odgovarjali na to vprašanje) meni, da bi morali določiti določen nivo predzna-
Opredelitev ciline skupine odraslin se zdi večini učiteljev kar primerna. nja tujega jezika, 4 (36\%), da bi moral biti kriterij starost in pri tem je en anketiranec zapisal »najmanj 16 let «, ostali pa se zavzemajo za testiranje udeležencev pred vključitvijo, kar sicer ni povsem $\mathrm{v}$ skladu $\mathrm{z}$ vprašanjem, $\mathrm{ki}$ smo ga postavili, kaže pa na to, da se zavzemajo za določitev predznanja kot vstopnega pogoja, zlasti $\mathrm{v}$ različne stopnje (semestre). Nekdo je tudi pripisal, da bi morali kot pogoj za vključitev $\mathrm{v}$ program določiti potrebe in želje posameznika po znanju tujega jezika, 
kar je $\mathrm{z}$ vidika določanja ciljne skupine (in $\mathrm{s}$ tem posledic na vstopne pogoje za program) zelo vprašljivo, kaže pa na to, da se očitno tudi v teh programih pojavljajo ljudje, ki nimajo zadostne motivacije, kar je moteče tako za učitelja kot skupino. Nemščina: 5 anketirancev je odgovorilo, da predlaga opredelitev določenega nivoja predznanja, predvsem pri višjih stopnjah. Nekdo pa opozarja, da bi z razvrščanjem na podlagi predznanja dobili starostno zelo heterogene skupine, kar se mu ne zdi ustrezno, in raje predlaga starostni kriterij. Temu mnenju sta pritegnila še dva anketiranca. Tudi tu so se pojavili odgovori, da bi bilo treba ugotavljati motivacijo udeležencev, kar kaže, da so s tem očitno povezani neki problemi. Italijanščina: tu so se odgovori razporedili kar tretjinsko: tretjina anketirancev meni, da bi morali kot kriterij opredeliti določen nivo predznanja, tretjina starost, tretjina pa ustrezno motivacijo. Pri francoščini pa ni bilo dodatnih predlogov.

Razvrščanje udeležencev jezikovnega izobraževanja glede na preznanje tujega jezika. Glede na to, da se je pri prejšnjem vprašanju večina anketirancev opredelila, da je ciljna skupina $\mathrm{v}$ programu ustrezno opredeljena, bi pričakovali, da bo večina anketirancev tudi pri tem odgovoru proti takemu razvrščanju. Učitelje smo namreč povprašali, če mislijo, da bi

\begin{tabular}{|c|c|c|c|c|c|}
\hline Jezik & $\begin{array}{l}\text { Rozumevonje } \\
\text { vsokcenjij } \\
\text { pistili besedi }\end{array}$ & $\begin{array}{l}\text { Rozumevanje } \\
\text { vsakdaniega } \\
\text { govorg }\end{array}$ & $\begin{array}{l}\text { Sposomonost } \\
\text { leloceggo in } \\
\text { geztovno } \\
\text { provinegagovora }\end{array}$ & $\begin{array}{l}\text { Sposolonost } \\
\text { pisaria } \\
\text { sokdanith } \\
\text { besechi }\end{array}$ & Drugo \\
\hline & A & B & $c$ & 0 & E \\
\hline angleséno & $2 \%$ & $26 \%$ & $17 \%$ & $21 \%$ & $14 \%$ \\
\hline nenšténa & $17 \%$ & $20 \%$ & $25 \%$ & $20 \%$ & $18 \%$ \\
\hline Iolijangetena & $2 \%$ & $25 \%$ & $28 \%$ & $125 \%$ & $125 \%$ \\
\hline troncosento & $20 \%$ & $20 \%$ & $20 \%$ & $20 \%$ & $20 \%$ \\
\hline
\end{tabular}

bilo dobro, da bi za vključitev v program imeli standardizirane teste (preskuse znanja) za razvrščanje udeležencev glede na predznanje tujega jezika. Rezultati so presenetljivi: kar $82 \%$ anketirancev se je izreklo za uvedbo standardiziranih testov in $\mathrm{s}$ tem za določanje predznanja kot značilnosti ciljne skupine. Vse to so vsekakor informacije, ki jih bo morala ekspertna skupina za prenovo programa resno vzeti v pretres.

Kakšni naj bodo globalni cilji izobraževanja? Vsi sedaj veljavni izobraževalni programi tujih jezikov za odrasle kot globalne cilje dolo- čajo "osvojitev besednega zaklada pogovornega in delno tudi pisnega jezika«. Učitelje smo povprašali, če se jim taka opredelitev zdi ustrezna. 34 anketirancev se je izreklo, da se jim zdi tak cilj ustrezen, 26-tim pa ni všeč. Tisti, ki z opredelitvijo niso zadovoljni, so napisali, da bi morali dodati še seznanjenost s kulturo in civilizacijo, predvsem pa opredeliti cilj kot sposobnost, da se posameznik dobro znajde v vsakdanjih življenjskih situacijah. Opredeljeno naj bi bilo kot dobro razumevanje, ustno in pisno izražanje. Ena izmed anketirank opozarja, da osvojen besedni zaklad še ne zagotavlja znanja jezika. ${ }^{11}$

Kakšni naj bi bili temeljni učni cilji programov tujih jezikov za odrasle? Anketirancem smo ponudili več trditev z možnostjo, da se odločijo za več odgovorov ali pa da dodajo svoje predloge. Gre namreč za eno izmed temeljnih vprašanj določanja izobraževalnega programa, ki vpliva na vse ostale njegove sestavine (vsebino, trajanje, izpitne kataloge itd.).

Ti rezultati nam kažejo nekoliko razlik med stališči učiteljev posameznih jezikov, saj npr. učitelji angleščine dajejo prednost razumevanju vsakdanjega govora, učitelji nemškega jezika pa sposobnosti tekočega in jezikovno pravilnega govora. V celoti pa je porazdelitev odgovorov približno enakomerna, iz česar lahko sklepamo, da bi bilo dobro med standarde znanja vključiti vse opisane kategorije. Med odgovori »drugo « so nam učitelji posredovali celo vrsto zelo koristnih predlogov, ki bodo ekspertom, ki se bodo ukvarjali s prenovo programov, prav gotovo $v$ pomoč. Glede na pogostost opozoril, da bi morali v program vključiti spoznavanje kulture dežele tujega jezika (tudi pri drugih vprašanjih), bo to vsekakor treba resno vzeti v pretres, prav gotovo pa to pomeni kar bistven poseg $\mathrm{v}$ sedanji program. Zanimiv je tudi predlog, da se standardi znanja opredelijo za posamezne stopnje, kar pomeni, da bi bile stopnje veliko bolj določene kot sedaj, morda tudi to, da bi program delili na več programov. Vsekakor pa ekspertni skupini ne bodo $\mathrm{v}$ pomoč stališča, da bi morali biti izobraževalni cilji bolj zahtevni in na drugi strani manj zahtevni.

Kakšne so najpogostejše organizacijske oblike izvedbe izobraževalnega programa? Pri predstavitvi programa smo že navedli, da program predvideva izpeljavo v 4 ali 5 seme- 
strih $\mathrm{z}$ nekoliko različnim trajanjem $\mathrm{v}$ urah. Povedati moramo, da smo dobili izredno pestre odgovore:

\begin{tabular}{|c|c|c|c|c|c|}
\hline \multirow[b]{2}{*}{ sopie } & \multirow{2}{*}{ 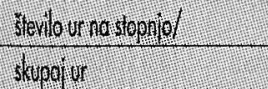 } & \multicolumn{4}{|c|}{ pogostost pojave } \\
\hline & & anglestero & nensecho. & 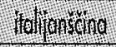 & tancoscing \\
\hline \multirow[t]{2}{*}{ is soprie } & 601180 & 1 & & & \\
\hline & $100 / 800$ & & 1 & & \\
\hline \multirow[t]{7}{*}{ Minsoprie } & $60080 / 241320$ & 1 & & 1 & \\
\hline & $80 / 320$ & 1 & & & \\
\hline & $80-160 / 320-640$ & 1 & & & \\
\hline & $90 / 80$ & & & 1 & \\
\hline & $100 / 400$ & 6 & 6 & 1 & 1 \\
\hline & $104-08$ & & 1 & & \\
\hline & 100120440480 & 1 & 1 & & \\
\hline \multirow[t]{9}{*}{ pel stopent } & $50776+100,12+130 / 468$ & 1 & & & \\
\hline & 80400 & 2 & 3 & & \\
\hline & $80,90 / 400.450$ & 1 & & & \\
\hline & $4 \times 80+1001420$ & & & 1 & \\
\hline & $90 / 450$ & 3 & 5 & 1 & \\
\hline & 100150 & 2 & 1 & & \\
\hline & $4 \times 100+40-50 / 440-450$ & & 1 & & \\
\hline & $4 \times 100+60 / 400$ & 1 & & & \\
\hline & $\begin{array}{l}4 \times 100+60 / 460 \text { d } 9 \times 50 / 450 \\
\text { di } 5 \times 80+50 / 40\end{array}$ & 1 & & & \\
\hline \multirow[t]{7}{*}{ sest soperi } & $40120 / 20790$ & & 1 & & \\
\hline & $5 \times 80+50$ za dikivno zenenje dí & & & & \\
\hline & priprovona izpit & & 1 & & \\
\hline & $5 \times 80+60 / 460$ & & 1 & & \\
\hline & $80 / 480$ & 2 & 2 & 1 & \\
\hline & $3 \times 00+3 \times 60 / 450$ & & & 1 & \\
\hline & $91 / 546$ & & & & 1 \\
\hline \multirow[t]{4}{*}{ seden stopent } & $60 / 42$ & & 1 & & \\
\hline & 70100 & & 2 & & \\
\hline & 90180 & 1 & 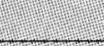 & & \\
\hline & $91.100167-700$ & 1 & 1 & & \\
\hline osen stopei: & 70150 & 1 & & & \\
\hline
\end{tabular}

Iz pregleda je razvidno, da se največ izvajalcev odloča za delitev programa na štiri ali pet stopenj, kar je nekako v skladu $\mathrm{z}$ določili veljavnega izobraževalnega programa, so pa tudi taki, ki program izvajajo $\mathrm{v}$ treh stopnjah ali pa kar osmih. Kaj lahko te ugotovitve pomenijo pri presoji programov? Očitno je, da se je v praksi uveljavila velika raznolikost glede izvedbenega segmentiranja programa. Predvidevamo, da za to raznolikostjo stojijo razlogi, ki so povezani s strokovnimi argumenti v posamezni izvajalski organizaciji, z lokalnimi razmerami in pričakovanji udeležencev, s tradicijo ipd.

Da bi bolje osvetlili problematiko, smo anketirance povprašali, kakšno je njihovo mnenje. Tako smo jim zastavili vprašanje, ali menijo, da je s programom določena delitev na stopnje ustrezna ali pa naj bo organizacijska izvedba prepuščena izvajalcem. Glede na velike razlike $\mathrm{v}$ organizacijskih izvedbah, ki smo jih že ugotovili, je bilo mogoče odgovore že vnaprej predvidevati. $77 \%$ vprašanih se je izreklo, da naj bo organizacija izvedbe prepuščena izvajalcem, pri čemer so kot razlog naštevali možnost prilagajanja učbenikom, slušateljem, letnim časom, napredovanju udeležencev, različnim metodam itd. Tisti, ki so bili za določene delitve, pa so navajali predvsem problem prehodov med stopnjami. Očitno je, da imajo učitelji dobre utemeljitve, zakaj ni smiselno predpisovanje organizacije programa. Skupina, ki se bo ukvarjala $s$ prenovo programa, pa ne bo mogla mimo opozoril, da se $\mathrm{z}$ razlikami med stopnjami pri posameznih izvajalcih zmanjšuje prehodnost med različnimi ustanovami, še zlasti $\mathrm{v}$ primerih, ko posamezne ustanove ne organizirajo izvedbe programa $\mathrm{V}$ celoti, pač pa samo njegov del, slušatelji pa so zato prisiljeni nadaljevati usposabljanje $\mathrm{v}$ drugih ustanovah.

Verjetno ni modro, da bi s programom natančno določali "pravilno" delitev, ampak je najbolje uporabiti kar priporočilo področne kurikularne komisije za izobraževanje odraslih, ki govori, da »sestavljalec programa predlaga najprimernejše oblike ..." in da "se moramo zavedati, da sestavljalec programa metod in oblik ne more dokončno določiti - to je zadeva izpeljave - saj je vsakokratni izobraževalni proces posebne narave ". ${ }^{12}$ Torej, sestavljalci pripravijo dve ali več različic, utemeljenih v ciljih programa in standardu znanja, izvajalci pa izbirajo najustreznejšo rešitev glede na konkretno skupino udeležencev.
Večina učiteljev

meni, da mora biti organizacija izvedbe prepuščena izvajalcem. 
Možna rešitev bi bila tudi ta, da bi obstoječi program delili na vač manjših zaključenih enot. Zato smo učitelje povprašali, ali menijo, da bi bilo smiselno pripraviti več krajših verificiranih programov. $Z a$ to idejo se navdušuje 34 anketirancev, kar je dobra polovica. Ideja očitno ni zanemarljiva in jo kaže še natančneje razmisliti. ${ }^{13}$

Ugotovljene razlike $\mathrm{v}$ izvedbi programa se ne zdijo zelo sporne, bolj vprašljivo pa je to, da različna delitev, razen pri izjemah, skoraj vedno pomeni tudi manj ali več ur. Dopuščamo, da je različno število ur deloma posledica različnega predznanja in intenzivnosti dela $\mathrm{v}$ skupini, sprašujemo pa se, ali lahko še govorimo o enakem programu, ki ima komaj $42 \%$ predpisanih ur ali pa jih presega za npr. $47 \%$ ? Seveda ne gre pozabiti, da posamezni

Dosedanji program

tujih jezikov za

odrasle nima

natančno določenih standardov znanja. izvajalci morda tečaje kombinirajo $\mathrm{z}$ organiziranim samoizobraževanjem ali pa na željo slušateljev dodajajo še druge vsebine. Glede na to, da program nima natančno določenih standardov znanja in da so delno poenotenje kriterijev vrednotenja znanja dosegli le med članicami Zveze ljudskih univerz Slovenije, pa se zdi upravičeno vprašanje, ali listine, ki jih dobijo slušatelji pri različnih izvajalcih, govorijo o približno enakem nivoju znanja.

V tej luči so še posebej zanimivi odgovori anketirancev na vprašanje, ali je število ur v programu glede na predpisano vsebino ustrezno. Da je število ur premajhno, se je odločilo 21 anketirancev. Kot podkrepitev svoje trditve so navajali, da je za ustrezno jezikovno znanje potrebnih več ur, saj odrasli običajno ne delajo veliko doma, zaradi česar morajo imeti na razpolago več ur za vaje; da je določeno število ur zlasti za začetnike premajhno; da se znanja ne da dovolj utrditi, ker ni časa za ponavljanje ipd. Preveč ur v programu se zdi le trem anketirancem. Največ, to je 34, anketirancev pa se je odločilo, da je sedanji obseg programa kar pravšnji.

Razumljivo je, da so mnenja anketiranih med seboj različna. Je pa mogoče iz teh razlik vseeno izbrati nekatera opozorila: ni dobro, da je obseg ur popolnoma določen, učitelj naj ima možnost prilagajanja glede na predznanje, motivacijo, interese slušateljev; standardi znanja niso enoznačno določeni, zaradi česar si jih učitelji zastavljajo različno, iz tega pa izvira njihova ocena o (ne)zadostnosti števila ur; zahtevano predznanje je vprašanje, ki zadeva tudi presojo o obsegu programa.

Kaj učitelji menijo o vsebini izobraževalnega programa? Naslednji sklop vprašanj smo namenili vprašanjem, povezanimi $z$ vsebino izobraževalnega programa. Že prej smo ugotavljali, da so učitelji kar zadovoljni z njo, zato so zanimive njihove utemeljitve. Za odgovor, da je vsebina zelo dobra, se je odločilo 6 anketirancev. Njihova mnenja so podobna kot mnenje ene izmed anketirank: »Glede na nivo predznanja, ki ga imajo udeleženci, je zelo dobra - zajema v glavnem vsa področja, situacije, $v$ katerih se bodo znašli kandidati v stiku s tujci. Mogoče bi bilo dobro zamenjati/prestaviti nekatere snovi v nižje/višje stopnje."

Največ, to je 53 anketirancev, se je odločilo za mnenje, da je vsebina programa dobra. Naj naštejemo nekaj utemeljitev: "Slušatelji imajo možnost spoznati več zvrsti jezika, slovnične strukture, besedišče. V programe bi bilo koristno vključiti več slušnega razumevanja, gostovanja >native speakerjev', predvsem pa posodobiti tematiko. Program dovolj dobro zajema funkcije, tematiko in strukturo jezika, malo večji poudarek bi lahko bil tudi na kulturi in civilizaciji tujega jezikovnega okolja. Po mojem mnenju je bolj pomebno kot vsebina vprašanje, kako to vsebino naučiti. Predpisana vsebina je prilagojena ciljem. Zelo dobro bi bilo, če bi lahko imeli možnost vsebino programa delno in občasno spreminjati, odvisno od potreb udeležencev. Program omogoča, da tečajniki pridobijo ustrezno znanje za razumevanje vsakdanjih pisnih, govornih besedil, da so sposobni nastopiti $\mathrm{v}$ vsakdanjih situacijah (verbalno), ter so sposobni pisati vsakdanja besedila. V celoti zajema iste vsebine kot ostali mednarodni programi na tej stopnji. «

Trinajst anketirancev pa se je odločilo za oceno, program je slab. Naj že na tem mestu.povemo, da nihče programa ni ocenil kot zelo slabega. Tisti, ki s programom niso najbolj zadovoljni, so povedali: "Vsebina je zastarela glede na razvoj na vseh področjih. Strinjam se le $z$ obsegom poznavanja slovničnih struktur. Zahtevnostni nivo bralnega in slušnega razumevanja, pisnega sporočanja in komunikacije 
se mi zdi prenizek. Prevelik je poudarek na izgovorjavi (sodobni jezikovni trendi opuščajo pomembnost izgovorjave - angleščina je svetovni jezik, ki ga govorijo različni govorci). Slovnično program vsebuje primerno količino za predviden nivo znanja, vendar $\mathrm{v}$ takem obsegu zmanjka časa za pogovor (tujega jezika se ne učimo le zaradi pravil, ampak zaradi uporabe teh pravil v pogovoru. «

Odgovori so bolj mnenjske narave, medtem ko nam prav natančnih dopolnitev ali sprememb ni uspelo pridobiti. Ekspertna skupina pa bo vsekakor lahko spremembe ali pa vztrajanje pri že opredeljenem naslonila na ta mnenja, še posebej, ker je mogoče tudi iz odgovorov na druga vprašanja ugotoviti skupne značilnosti. Smo pa želeli konkretno izvedeti, ali bi in kaj bi učitelji med vsebinami črtali ali dodali.

Pri programu za angleški jezik se je za možnost črtanja odločila slaba tretjina anketiranih. Moti jo predvsem: terminologija družbenoekonomske ureditve ter samoupravnih odnosov; poglavja o melodiji govora v programu Headway pre-intermediate, ker so takšne in podobne naloge dlakocepske in dolgočasne; teme: vojna, ločitve, življenje v vesolju - to so zastareli in neaktualni teksti; življensko neuporabne, hipotetične ali izmišljene vsebine; Present Perfect Continuous, modalni glagoli ought to, dare, Conditional Clause ker to $\mathrm{v}$ vsakodnevnih pogovorih ne bo prišlo velikokrat v poštev. Nekdo pa opozarja, da je primernost vsebin odvisna tudi od ambicioznosti skupine: včasih je treba določene vsebine črtati, drugič pa dodajati.

Prav tako imajo učitelji angleščine precej predlogov za dopolnitev programa. Za tako možnost sta se odločili kar dve tretjini anketirancev. Predlagajo naslednje dopolnitve: več pisanja, (npr. sestavljanje pisem ipd.), teme o medkulturnem povezovanju, o angleščini kot svetovnem jeziku (jezik sporazumevanja med različnimi narodi), več prilagoditev na sedanje življenje in dogajanje doma in po svetu, več kulturoloških vsebin, več slušnega razumevanja in vaj iz pisanja - samostojni izdelki. Teme naj bodo posodobljene in naj vključujejo npr. bonton, razlike med kulturami, druženje, na višjih stopnjah bi bilo dobro dodati splošne poslovne izraze (navezovanje stikov s poslovnimi partnerji, poslovna pisma, telefonski pogovori), določeno naj bo, da učitelj lahko določene teme dodaja ali črta, moderni izrazi, amerikanizmi, uporabne situacije $\mathrm{v}$ prostoru in času ter prilagojeni dodatek za posebne namene (strojništvo, računalništvo ipd.), predstavitev tujega jezika, njegovo razumevanje in primerjava $\mathrm{z}$ maternim jezikom.

Učitelji si želijo, da bi bil v programu določen del namenjen vsebinam, ki bi jih sami dodajali glede na interese slušateljev, nadalje določen del programa, namenjen sodobnemu dogajanju doma in v deželi izbranega jezika, ter možnost spoznavanje kulture narodov, ki govorijo izbrani jezik.

Nekaj podobnega so povedali tudi učitelji nemškega jezika. Tudi tu se je za črtanje dela programa odločila dobra tretjina anketiranih učiteljev nemščine. $\mathrm{V}$ obstoječem programu niso najbolj zadovoljni z naslednjimi vsebinami: terminologija, ki zadeva organizacijo združenega dela in terminologijo družbenoekonomske ureditve ter samoupravnih odnosov, določene prezahtevne slovnične strukture, nezanimive so teme o domovih za ostarele, določene teme iz »deželoznanstva «, teme o zdravju, lekarnah, o medijih, socialistični teksti v učbeniku Deutsch aktiv (kopanje premoga, industrija).

Razen zastarele terminologije in opozoril na določene prezahtevne slovnične strukture gre predvsem za tematiko, ki jo določajo neobvezni učbeniki, zaradi česar sestavljalcem programa ne bo potrebno veliko spreminjati obstoječega programa. Še več kot pri učiteljih angleščine, kar $71 \%$ učiteljev nemščine predlaga nove vsebine: nekoliko bolj "poslovno" obarvane vsebine, več o literaturi, kulturi, ekologiji in splošno o politiki, opis in poznavanje Slovenije, posodobiti ustno in pisno komunikacijo, več poudarka na življenskih situacijah, moderni pisni komunikaciji, vključevanje vsebin in tekstov ožje specializacije, upoštevajoč interese slušateljev, večji poudarek na interkulturnem učenju tujega jezika, več o delu in poklicih, več šaljivih, zabavnih besedil, šal, pregovorov, krajših literarnih tekstov, pravljic, krajših časopisnih notic, več gradiva o naravi, kulturi, športu - za mlade ljudi je premalo lekcij o športu oziroma nobene. Več razmišljujočih tekstov, o katerih se lahko napiše spis, mnenje, kar udeleženci potrebujejo (glede na zaposlitev, svoje interese ...). Predlogi so dokaj podobni tistim, ki 
smo jih srečali že pri angleščini. Morda je nekoliko več poudarka na dodajanju vsebin, povezanih s Slovenijo.

Tudi učitelji italijanskega in francoskega jezika opozarjajo, da bi iz programa kazalo črtati zahtevnejše in redkejše slovnične strukture, ki se v vsakdanjem jeziku redkeje uporabljajo, predlagajo pa več poudarka na ustni in pisni komunikaciji, življenjskih situacijah in moderni pisni komunikaciji.

Glede na rezultate ankete bodo tisti, ki se bodo ukvarjali s presojanjem obstoječih programov za tuje jezike, pred dokaj enostavno nalogo, kako posodobiti obstoječe teme in kaj bi kazalo črtati, medtem ko bo verjetno nekaj več težav pri odločanju, kaj dodati novega. Nedvomno bo potrebno odgovoriti kar na nekaj strokovnih vprašanj: kje npr. potegniti ločnico med splošno in strokovno tematiko, ali in koliko literature izbranega jezika vključiti v program ipd. Še posebej bo to vprašanje pomembno v povezavi z idejami, da bi bili standardi znanja tega programa ekvivalentni standardom znanja maturitetnega tujega jezika. Vsekakor naloga, ki ni prav enostavna, čeprav bi že na tem mestu kazalo opozoriti, da si verjetno ne bi naredili dobre usluge, če bi radikalno spreminajli nekaj, kar je kljub vsemu v praksi dokaj dobro delovalo.

Kaj pa učbeniki in druga učna sredstva? Učitelje smo povprašali, kakšne učbenike in učna gradiva uporabljajo sami, kakšna pa udeleženci. Marsikateri anketiranec se je odločil za dokaj posplošen odgovor: uporabljam/o učbenik, tekste, avdio in video kasete, računalnik, razpredelnice ipd. Iz teh odgovorov lahko razberemo le to, da učitelji uporabljajo multimedijske vire znanja, kaj več pa ti odgovori ne pripovedujejo. Nekateri učitelji pa so, tako kot smo pričakovali, navedli konkretne učbenike, ki jih uporabljajo za lastno delo ali/in za udeležence. ${ }^{14}$

Poleg teh virov so učitelji angleščine navajali, da uporabljajo še angleške in ameriške časopise, klasična knjižna dela, različne video kasete (o Angliji, o angleških muzejih, razne posnetke z BBC Prime), lastne avdio kasete (posnete na seminarjih), lastne programe, slovarje, internet, radijske oddaje. Na splošno lahko ugotovimo, da so učitelji angleščine kar zadovoljni z razpoložljivimi učbeniki in učnimi gradivi. Tako se jih je izreklo $89 \%$. Pravijo, da jim je všeč, ker je na razpolago dovolj ustreznega gradiva. Nekdo je pripomnil, da učitelji nikoli niso povsem zadovoljni z učbenikom in vsakemu dodajajo nekaj svojega. učnimi gradivi zadovoljni učitelji nemščine. Tako se jih je izreklo $96 \%$. Posebej so pohvalili to, da so gradiva multimedijska, tako da so primerna za različne učne tipe (vizualne, avditivne, verbalne).

Prav vsi učitelji italijanščine so napisali, da so $\mathrm{z}$ učbeniki zadovoljni, niso pa podrobneje utemeljevali svoje ocene. Je pa treba opozoriti, da so nekateri učitelji italijanščine pri splošni oceni programa napisali, da je na razpolago premalo učbenikov in učil za učitelje.

Očitno je, da učitelji povečini uporabljajo iste učbenike in učila, kot jih priporočajo slušateljem, nekaj pa je tudi dodatnih, ki jih verjetno uporabljajo za popestritev ali dodajanje vaj. Iz ankete tudi ni, vsaj kar zadeva učbenike, opaziti velikih razlik med posameznimi izvajalci. Seveda gre pri tem pregledu le za grobo sliko; če bi hoteli delati natančne primerjave, bi morali ugotavljati, katere učbenike uporabljajo na posameznih stopnjah. Razveseljivo je tudi dejstvo, da učitelji (vsaj del njih) uporablja zelo veliko multimedijskih učnih virov, da so pri tem zelo iznajdljivi in inovativni. Res pa je tudi, da je učnih pripomočkov, vsaj za nekatere jezike, resnično veliko na tržišču, tako da učitelji lahko izberejo najprimernejše.

Bolj neugodno je to, da niso bili redki učitelji, ki so nam na to vprašanje napisali, da uporabljajo predpisane učbenike in učila. Ker smo že povedali, da program niti učbenikov niti drugih učnih virov ne predpisuje, se sprašujemo, kdo učiteljem "zapoveduje «, kakšne učbenike naj uporabljajo, še zlasti, ker se učitelji hkrati pritožujejo, da so nekateri slabi oz. neprimerni.

Preverjanje in ocenjevanje znanja. Večji sklop vprašanj smo namenili preverjanju in ocenjevanju znanja. Tako smo učitelje najprej povprašali, kako ocenjujejo oblike in načine preverjanja znanja, določene v programu. Kar $79 \%$ vseh anketiranih učiteljev ocenjuje, da je način preverjanja znanja primeren. Kljub razmeroma zelo dobrim ocenam pa so učitelji opozorili tudi na slabosti: »Testi so prelahki, premalo je poudarka na slovnici. Kriteriji pa so absolutno preblagi. Primerno bi bilo sprotno preverjanje znanja, na primer po obravnavani lekciji, slovnični strukturi. Mi smo preverjali znanje le ob koncu programa.

Test je zastarel. Zaključno preverjanje je po- 
trebno nujno posodobiti. Kriterij ocenjevanja je včasih prepuščen subjektivnemu občutku! Pisni in ustni del - oba sta zastarela. "

Očitno gre za opozorila, ki jih vsekakor kaže upoštevati, še zlasti tista, ki opozarajjo na preveliko možnost subjektivnega ocenjevanja, zastarelost, ne dovolj dodelane kriterije. $\mathrm{Ni}$ pa tudi tu, tako kot že pri splošnih ocenah programa, mogoče spregledati dejstva, da so učitelji ocenjevali različne stvari: nekateri pač samo tisto, kar je zapisano v programu, drugi tudi dodatne kriterije in napotke ter teste, $\mathrm{ki}$ so nastali v okviru Zveze ljudskih univerz Slovenije, ki so verjetno marsikomu dobrodošel pripomoček, niso pa sestavni del programa, ker pač nihče ni izvedel postopka potrditve tega gradiva na ustreznem strokovnem svetu. Še enkrat lahko ugotovimo, da za potrdili o znanju tujega jezika, ki jih dajejo različni izvajalci, niso enotni ali vsaj usklajeni kriteriji.

Glede na to, da smo že ugotovili, da vsi izvajalci izvajajo program po stopnjah, ki so relativno zaključene enote, je še posebej zanimivo vprašanje, ali učitelji menijo, da bi bilo dobro, če bi program vseboval obvezne kriterije za ocenjevanje znanja za napredovanje $\mathrm{v}$ programu, skratka, standard znanja, ki ga mora doseči posameznik, da lahko napreduje $\mathrm{v}$ višjo stopnjo. Velika večina učiteljev, to je $83 \%$, meni, da bi moral program vsebovati take kriterije za napredovanje. To stališče pojasnjujejo $s$ tem, da udeleženci svoje znanje precenjujejo in se vpisujejo $\mathrm{v}$ stopnje, $\mathrm{v}$ katere ne sodijo; da je delo v skupini slušateljev $\mathrm{z}$ enakim predznanjem neprimerno lažje tako za učitelja kot udeležence; da je bolje, če veljajo isti kriteriji za vse v Sloveniji, zaradi česar ne bi bilo problemov pri selitvah, prehodih $\mathrm{v}$ nadaljevanje $\mathrm{v}$ drugih ustanovah. Sprašujemo pa se, kako ta svoja pričakovanja učitelji združujejo z odločnim stališčem, da ne želijo, da bi program določal delitev na stopnje/semestre. Če to v programu ne bo določeno, tudi ni mogoče pripraviti enotnih kriterijev, standardov znanja za posamezno stopnjo.

Posebej se nam je zdelo pomembno, da pri učiteljih preverimo, kako ocenjujejo idejo, da bi tudi v slovensko jezikovno izobraževanje uvedli sistem zunanjega preverjanja znanja. Do zamisli, da bi učitelje povprašali o tem, smo prišli na podlagi tega, ker se je $\mathrm{v}$ Sloveni- ji v zadnjem času uveljavilo kar precej mednarodnih izpitov (ICC, mednarodni izpiti univerze Cambridge, mednarodni izpiti univerze Oxford, DALF, DELF, TOEFL, izpiti Goethejevega inštituta, CIL ipd.). Očitno je, da obstaja kar velika potreba po zunanjem preverjanju znanja. Hkrati nas je zanimala ta ideja iz razloga, ker je novi Zakon o izobraževanju odraslih drugače opredelil vlogo Državnega izpitnega centra, ki se je doslej ukvarjal pretežno $\mathrm{z}$ maturo, $\mathrm{v}$ bodoče pa naj bi izgrajeval in izvajal različne izpitne sisteme, zlasti na področju izobraževanja odraslih. Razmišljanja so, da bi kot prvi tak sistem uvedli »državni izpit/certifikat « za znanje tujega jezika. Pričakovali smo, da bo mnenje učiteljev približno enako razporejeno na tiste, ki bodo iz

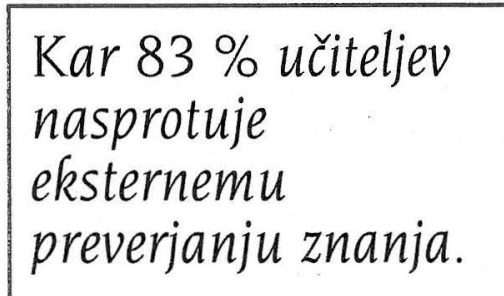
opisanih razlogov idejo podpirali, in na tiste, ki bodo do te novosti skeptični. Rezulati te naše predpostavke niso potrdili. Kar $83 \%$ učiteljev je bilo odločno proti taki ideji. Navajamo samo nekaj najbolj značilnih utemeljitev: »To bi bil prevelik pritisk na slušatelje in predavatelje. Končni test (po 450 urah) je v večini primerov že eksteren (certifikati). Do takrat pa naj imajo predavatelji proste roke, kako do cilja. Menim, da eksterno preverjanje ni potrebno, če so določeni standardi. Prav tako vidim problem organiziranosti in financiranja eksternega preverjanja. Pri vsaki ljudski univerzi je dovolj kvalificiranih učiteljev tudi za preverjanje znanja; sedanji način slušateljem ustreza. Pri odraslih je faktor lastnega nezaupanja in strah pred porazom zelo velik. Motivacija bi zelo padla. Učitelji smo sposobni sami oceniti znanje, potrebno je zaupanje. Bojim se sindroma mature: tečaj kot dresura za izpit. Udeleženci s svojim znanjem oz. neznanjem sami potrjujejo rezultat preverjanja znanja in kredibilnost ustanove, kjer so si to znanje pridobili. To bi bilo vse preveč podobno osnovni in srednji šoli in preveč stresno. Učenje je zabavno! Ne glede na moje mnenje bo do tega prej ali slej moralo priti. Upam le, da bo eksterno preverjanje dovolj dobro opravljeno oziroma, da se s tem zahtevnim projektom ne boste prenaglili. «

Vsekakor argumenti, ki jih kaže resno pretresti. Očitno je, da so učitelji vprašanje razumeli kot namig, da bi tako preverjanje znanja 


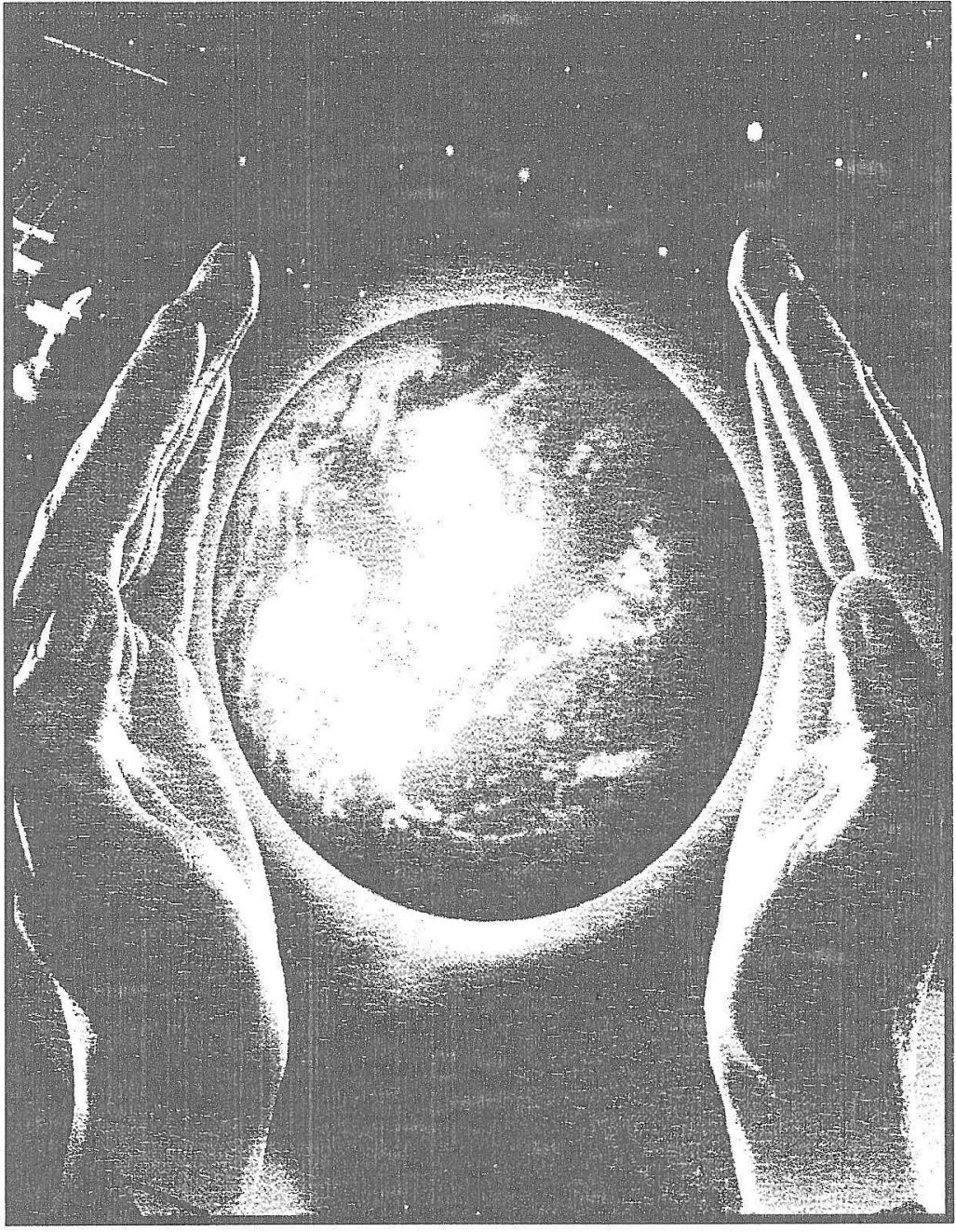

postalo obvezno, čeprav tega nismo trdili. Zato tako pogosto opozarjajo, da bi morala biti to možnost, ki jo izkoristi tisti, ki si to želi, kar se tudi nam zdi smiselno. Pojavili so se podobni, ne trdimo, da ne tehtni, ugovori, ki so se pojavljali pri uvajanju eksternega ocenjevanja na maturi ali ob pripravah na spremembo osnovne šole. Iz nekaterih odgovorov veje že kar užaljenost, češ da gre za nezaupanje učitelju in ustanovi, čeprav isti učitelji in ustanove izvajajo mednarodne izpite, pa nismo zasledili kakšnih posebnih ugovorov proti temu. In če smo resnicoljubni: tudi na verifikacije (beri: licence) ustanov za izvajanje posameznih programov se ne kaže zanašati povsem, saj vemo, da je ob pretežno zunanjih sodelavcih fluktuacija osebja zelo velika, kadrovski pogoji pa se preverjajo samo v postopku pridobivanja verifikacije. Nekateri kar neposredno povedo, da že imamo mednarodne izpite, zaradi česar ni potrebe po slovenskih. Kaže pa pritegniti vsem tistim, ki opozarjajo, da eksterno preverjanje prinaša dodatne stresne situacije tako udeležencu kot učitelju. Tudi organizacijsko in finančno zadevo verjetno ne bi bilo prav lahko izpeljati.

$V$ nadaljevanju smo postavili še bolj »provokativno« vprašanje. Učitelje smo povprašali, kaj menijo o tem, da vzgojnoizobraževalni program z vsemi sestavinami sploh ne bi bil določen, pač pa bi bilo organizirano zgolj eksterno preverjanje znanja, seveda $z$ določenimi standardi znanja. Kvaliteto programa, učitelja, ustanove bi preverjali le prek uspeha udeležencev. Učitelj bi bil v tem primeru povsem avtonomen: ob postavljenih standardih znanja bi skupaj z udeleženci določal trajanje izobraževanja, program, učbenike, metode itd.

Po pričakovanju se učitelji tudi za tako idejo niso preveč zagreli. $37 \%$ odgovorov je idejo potrdilo kot sprejemljivo ali celo navdušujočo, pri čemer se jim zdi dobro to, da ima posameznik možnost, da preveri znanje, ki si ga je pridobil na kakršenkoli način, ker tak način dovoljuje učitelju, da se $\mathrm{v}$ največji meri prilagodi skupini, da doseže želen rezultat, in navsezadnje zato, ker bi se povečala kvaliteta posameznih izvajalcev tega programa. Večina pa vidi v takem predlogu več slabosti ali nevarnosti. Opozarjajo, da je to daljša pot do rezultata, da bi se lahko dogajalo marsikaj v škodo udeležencem, da je ta način preveč ciljno usmerjen in samo končno preverjanje znanja ni zadostno. Nekateri se bojijo, da bi bilo učenje prilagojeno zgolj izpitu, so pa tudi taki, ki so preprosto proti ali pa navajajo, da se ne morejo opredeliti. Vsekakor pa odstotek tistih, ki so se za idejo navdušili, ni tako majhen; morda bi kazalo razmišljati o uvedbi eksperimenta. Moramo pa ugotoviti tudi to, da vsi anketiranci niso dobro razumeli vprašanja. Tako nekateri pišejo, da bi morali biti določeni standardi znanja, kar je povsem jasno, da se nekateri odrasli učijo za lastno zabavo, in ne za izpit (kar pomeni, da se eksternega preverjanja pač ne bi udeležili) ipd.

Samo ugibamo lahko, ali se stališča razlikujejo tudi glede na izobrazbo ali še bolje usposobljenost posameznih učiteljev. Opazno je namreč, da so nekateri navdušeni nad strokovno avtonomijo, ki bi jim jo taka ureditev ponujala, drugi pa so zaskrbljeni nad tem, da ne bi imeli trdne opore ali vodila v programu. Med resnimi strokovnimi "protiargumenti « kaže izpostaviti mnenje, da bi taka rešitev vo- 
dila k ciljno naravnanemu poučevanju, ki pa ne bi izražalo vsega znanja posameznika. Zgodilo bi se lahko, da bi poučevanje postalo uniformirano, saj bi bilo vse podrejeno izpitom. Tudi možnosti šarlatanstva so večje: če ne bi bili postavljeni kriteriji, kdo se s tovrstnim izobraževanjem lahko ukvarja, bi se dogajalo to, kar se danes tako ali tako dogaja pri neverificiranih programih - izvajajo jih tudi tisti, ki niso najbolje usposobljeni, posledice pa nosijo predvsem udeleženci.

$\mathrm{Pa}$ še o usposobljenosti učiteljev. Glede na dokaj razširjeno strokovno mnenje, da formalna izobrazba, ki se zahteva za poučevanje odraslih, ne zadostuje, smo vprašali tudi učitelje, kaj menijo o tem. Vprašali smo jih, ali bi moral program poleg pogojev, ki jih določa zakonodaja, določiti še kaj drugega za izvajalce programov tujih jezikov. Mnenja so deljena: približno polovica anketiranih (48 \%) poudarja, da je formalna izobrazba premalo. Res pa je, da je med predlogi, ki jih dajejo, malo takih, ki so objektivno merljivi. Med drugim navajajo: pomembno je veselje in ljubezen do tega dela, izvajalci programov bi prav tako morali opraviti test, preden bi prevzeli določeno stopnjo tečaja, predavateljem manjka sodobnejše andragoško znanje in poznavanje sodobnejših dognanj s področja metodike in tehnik dela $\mathrm{z}$ odraslimi. Potrebno je redno dodatno izobraževanje, nekateri predlagajo, da bi bilo to obvezno. $\mathrm{V}$ zvezi s tem pa opozarjajo, da ni dovolj različnih in kvalitetnih programov za učitelje. Imeti bi morali tudi izpopolnjevanje $v$ tujini. Poudarjajo tudi, da so boljši redno zaposleni učitelji (ti imajo čut odgovornosti), zahteva naj se udeležba na seminarjih, dodatno izobraževanje, zlasti iz metodike poučevanja odraslih. Pred pričetkom poučevanja bi bilo dobro, če bi na vseh zavodih organizirali hospitacije, pogovore in teste. Niso pa bila tako redka opozorila, da marsikje izvajajo izobraževanje odraslih na tem področju ljudje, ki za to niso formalno usposobljeni. Glede na to, da gre za verificirane izvajalce, bi morala biti taka opozorila odveč. Samo ugibamo lahko, če so anketiranci opozarjali na razmere pri jezikovnem izobraževanju nasploh (tudi pri neverificiranih programih, kjer izobrazbene zahteve niso določene ali pa jih vsaj nihče ne nadzoruje) ali pa ...

Očitno je, da je formalna izobrazba ob stal- nem strokovnem izpolnjevanju to, kar po mnenju večine učiteljev zadostuje. Prvo lahko rešujemo z zakonom, o drugem pa bi morali razmisliti, saj stalno izpopolnjevanje zahteva tudi neke vrste stalno spremljanje. Morda je rešitev $\mathrm{v}$ obnovljivih licencah? Zanimivi so tudi predlogi o stalni zaposlitvi osebja, kar pa bi za marsikatero ustanovo predstavljalo velik problem. Res pa je tudi, da je vprašanje, ali je dobro, da imajo ustanove, ki izvajajo zelo veliko tovrstnega izobraževanja, večinoma zunanje sodelavce.

\section{NAMESTO SIKLEPA}

Namen tega prikaza ni, da bi delali zaključke, ali in kaj je treba v izobraževalnih programih za jezikovno izobraževanje odraslih spreminjati ali dopolnjevati. To bodo storili tisti, ki bodo kot eksperti proučili program, rezultate tega anketiranja in druga strokovna gradiva. Vsako drugo sklepanje bi bilo nestrokovno prevzemanje njihove vloge. Namen tega prikaza je bil kar najbolj verno prikazati, kaj, ne zanemarljivo velika, skupina učiteljev meni o teh programih, kakšne so njihove praktične izkušnje, kaj jih moti in česa za vsako ceno ne bi hoteli pogrešati. Rezultati so namenjeni tudi njim, da bodo svoje ugotovitve lahko primerjali z drugimi, da bodo morda dobili kak napotek ali idejo. Prikaz namenjamo tudi tistim, ki se ukvarjajo z verifikacijo teh programov in njihovih izvajalcev. Zaključujemo pa ga $z$ besedami samih anketirancev, ki so nam jih namenili na koncu anket:

- Posodobitev teh programov je nujna, da bomo lahko uskladili naše delo s programom. Pri delu smo učitelji te programe že zdavnaj presegli.

- Sodelujem tudi kot ocenjevalec na maturi. Angleške programe tako zelo dobro poznam, učim na strokovni šoli in mislim, da so naši programi in učbeniki izredno dobro pripravljeni.

- Koncept sedanjega programa je dober, če ga institucija nenehno posodoblja in sproti aktualizira, kar naj se odraža tudi pri sprotnem in končnem preverjanju.

- Ni vsaka noviteta dobra, kot tudi ni vse staro zanič!

- Glede na precejšno zastarelost programa, ki ne ustreza oziroma ne sledi razvoju na po- 
dročju izobraževanje odraslih, menim, da bi bilo najprej potrebno napisati nov program in šele nato učitelje spraševati za mnenje (o novem, prenovljenem programu).

- Dobro bi bilo, če bi sklicali sestanek izvajalcev verificiranih jezikovnih programov in da bi program oblikovali ljudje iz prakse. Pomembno je tudi, da so oblikovalci programa iz različnih regij oz. izobraževalnih ustanov.

- Poleg dobrega programa bi bilo potrebno poskrbeti tudi za boljše pogoje dela, za primerne učilnice, AV-sredstva - brez tega še tako dobri programi zvodenijo.

\begin{abstract}
${ }^{1}$ Po že omenjenemu členu zakona so to programi za zviševanje splošnoizobraževalne in kulturne ravni prebivalstva, funkcionalno opismenjevanje, spopolnjevanje znanja za delo in poklic, za izobraževanje in usposabljanje brezposelnih, izobraževanje za demokracijo, učenje tujih jezikov, učenje slovenskega jezika za tujce, izobraževanje za kvaliteto življenja, izobraževanje za uveljavljanje posebnib pravic manjšin in odraslib s posebnimi potrebami in posebnib skupin ter drugo splošno izobraževanje odraslih.

${ }^{2} \mathrm{~V}$ besedilu uporabljamo izraz verificirani izobraževalni program, ki se je v izobraževanju odraslih uveljavil pri tistih izobraževalnih programih, ki so sprejeti na način, določen z zakonom, in dajejo javno veljavno izobrazbo ali znanje, potrjeno z javno veljavno listino. Izraz ni najboljši, je pa v praksi zelo uveljavljen. Če bi ga nadomestili z izrazom "jauni program ", labko pride do zmede, ker se $v$ zadnjem času ta izraz uporablja tudi za izobraževalne programe, ki niso mijno javno sprejeti/potrjeni, pačpa se (so)financirajo iz jaunih sredstev.

${ }^{3}$ Vsi omenjeni izobraževalni programi so sestavljeni po enotni metodologiji - še več: večina besedila je identična, razlike so le $v$ poglavju o slovničničnih strukturah. Zato $v$ nadaljevanju za vse obravnavane izobraževalne programe večkrat uporabljamo kar ednino, npr. "program do-
\end{abstract} loča ... «

${ }^{4}$ Tu je $v$ izobraževalnem programu prvič uporabljen izraz "stopnja «. Glede na to, kar smo že povedali o organizaciji izvedbe izobraževalnega programa, predvidevamo, da se izraz uporablja kot ekvivalent za semester. $Z$ drugimi besedami bi to pomenilo, da so zaključni testi predvideni ob koncu vsakega semestra.

${ }^{5}$ Npr.: izbirni test obsega 45 struktur, pisni sestavek mora obsega usaj 1 stran A4 formata, pri čemer kandidat izbira med petimi temami iz družbenega delovanja in osebnega življenja.

${ }^{6}$ Razmejitev med vlogo uciteljev in zunanjih sodelavcev iz besedila izobraževalnega programa ni razvidna. Predvidevamo, da so z učitelji mišljeni tisti učitelji, ki so $v$ rednem delounem razmerju $v$ izobraževalni organizaciji, zunanji sodelavci pa so prav tako učitelji, le da niso zaposleniv izobraževalni organizaciji. Tako sklepanje je mogoče na podlagi opisa, kakšne izobrazbene pogoje morajo izpolnjevati.

${ }^{7} \mathrm{Od}$ tega dveh anket nismo mogli upoštevati, ker sta respondenta navedla, da ne poučujeta $v$ teh izobraževalnih programih, mi pa smo poučevanje v njih opredelili kot kriterij za sodelovanje $v$ anketi.
${ }^{8}$ Pri prikazu rezultatov anketiranja je treba upoštevati, da vsi anketiranci niso odgovorili na vsa vprašanja, zato se pri posameznih vprašanjih pojavlia tudi drugačno skupno število odgovorov.

${ }^{9} \mathrm{~V}$ tem sestavku navajamo samo najpomembnejše rezultate. $Z$ vsemi rezultati so seznanjeni člani ekspertne skupine pri programski kurikularni komisiji, na vpogled pa so tudi v arhivu ACS.

${ }^{10}$ Glej npr. članek dr. Roberta Krofliča: Kurikulum. Raznourstnost kurikularnega načrtovanja. Andragoška spoznanja, 1/97.

11 Tri anketiranke pa so menile, da program dejansko bolje opredeljuje globalne izobraževalne cilje in da jib vprašanje v anketi ne povzema ustrezno. Z njimi bi se bilo mogoče strinjati, če gledamo program v celoti, saj se cilji izobraževanja $v$ različnem besedilu deloma pojavljajo $v$ več poglavjih (npr. dela in naloge, za katera usposablja program, učni načrt ipd.), kar kaže na precejšnjo metodološko nedoslednost pri izdelavi programa.

12 Izhodišča za kurikularno prenovo izobraževanja odraslib in za oblikovanje programov za izobraževanje odraslib. Področna kurikularna komisija za izobraževanje odraslih, julij 1997.

${ }_{13}$ Nekateri, ki so se zanjo navdušili, so pripisali, da jo podpirajo, pri čemer naj za pridobitev potrdila o aktivnem znanju tujega jezika ostane doľ̌ina programa 450 ur, smiselno pa bi bilo imeti tudi krajše verificirane programe, s katerimi bi si udeleženci pridobili potrdila o opravljeni usposobljenosti za sporazumevanje $v$ vsakdanjih situacijah ipd., če bi to želeli (model bi labko bil podoben angleškemu). Dobro bi bilo razmisliti o uvedbi t. i. certifikatnega sistema, $v$ katerem bi labko udeleženci dobili verificirano potrdilo že po npr. 200 urab učenja tujega jezika. To naj bi bila možnost za tiste, ki si to želijo. S tem bi izbolišali ponudbo.

${ }_{14}$ Angleščina: The New Cambridge English Course. Student 1, 2, 3, 4. Practice and Key 1, 2, 3, 4. (Cambridge University Press) - Person to Person (BBC, Linguarama) - Progress to First Certificate (Cambridge) - Grapevine 1, 2, 3 (učbeniki, delovni zvezki, AV-kasete - Oxford University Press - Hutchinson: Pre-intermediate, Intermediate (učbeniki, delovni zvezki, AV-kasete - Oxford University Press - First Certificate Masterclass (učbenik, delouni zvezek, AV-kasete - Oxford University Press Reward: Pre-intermediate (Oxford) - Headway: Pre-intermediate, Intermediate, Upper-intermediate (Oxford University Press) - Fowler: Test and Practice your English (Walton on Thames, Edinburg). Nemšcina: Velkaverh: Deutsch Perfect 1-4 (DZS, Ljubljana) - Sprachkurs Deutsch 1-7 (Frankfurt) - Themen neu 1-3 (Max Hueber Verlag) - Deutsch aktiv (Berlin) - Vorderwulbecke: Blick auf Deutschland (Stuttgart) - Baltzer: Alles gute! (Berlin) - Muster-Čenčur: Beremo nemško (CZ, Ljubljana) - Duden (bungen (Mannheim) - Vorderwulbecke: Stufen international (Stuttgart) - Eichheim: Mit Erfolg zum Zertifikat (München) - Sichtwechsel: Elf Kapitel zur Sprachsensibilisierung (Stuttgart) - MusterČenčur: Nemška slovnica po naše (CZ, Ljubljana); Unternehmen Deutsch (München). Italijanščna: Katerinov: La lingua italiana per stranieri (Perugia); Buongiorno 1-2 (DZS, Ljubljana) - Imparare dal vivo (Roma) - Chiuchiu: In Italiano (Perugia) - Lenassi: Studiamo insieme (Reka). Za francoščino nismo dobili konkretnih podatkov. (Podatki niso navedeni bibliografsko, ker na tem mestu ni mogoče navajati useh avtorjev in izdaj; napisali smo le tiste podatke, ki so pomembni za razpoznavanje učbenikov, ki se najpogosteje uporabljajo.) 